\title{
Correction to: Population Pharmacokinetic Evaluation of Amikacin Liposome Inhalation Suspension in Patients with Treatment-Refractory Nontuberculous Mycobacterial Lung Disease
}

\author{
Christopher M. Rubino ${ }^{1}$ - Nikolas J. Onufrak ${ }^{1}$ Jakko van Ingen ${ }^{2}$. David E. Griffith ${ }^{3,4}$ - Sujata M. Bhavnani ${ }^{1}$. \\ Dayton W. Yuen ${ }^{5} \cdot$ Kevin C. Mange ${ }^{5} \cdot$ Kevin L. Winthrop ${ }^{6}$
}

Published online: 19 April 2021

(c) The Author(s) 2021

\section{Correction to: \\ European Journal of Drug Metabolism and \\ Pharmacokinetics (2021) 46:277-287 \\ https://doi.org/10.1007/s13318-020-00669-7}

The original version of this article unfortunately contained a few errors. The correct information is given below:

Page 281, 1st paragraph, 2nd sentence, which previously read:

The serum samples in TR02-112 were clustered in two primary windows $-0-4 \mathrm{~h}$ and $12-24 \mathrm{~h}$ postdose (Fig. 1).

Should read:

The serum samples in TR02-112 were clustered in two primary windows $-0-4 \mathrm{~h}$ and $12-24 \mathrm{~h}$ postdose (Fig. 2).

The original article can be found online at https://doi.org/10.1007/ s13318-020-00669-7.

Christopher M. Rubino

crubino@icpd.com

1 Institute for Clinical Pharmacodynamics, Inc, 242 Broadway, Schenectady, NY, USA

2 Department of Medical Microbiology, Radboudumc Center for Infectious Diseases, Radboud University Medical Center, Geert Grooteplein 10, 6525 GA Nijmegen, The Netherlands

3 The University of Texas Health Science Center at Tyler, 11937 US Highway 271, Tyler, TX, USA

4 Present Address: National Jewish Health, 1400 Jackson St, Denver, CO 80206, USA

5 Insmed Incorporated, 700 US-206, Bridgewater, NJ, USA

6 Oregon Health and Science University, 3375 SW Terwilliger Boulevard, Portland, OR, USA

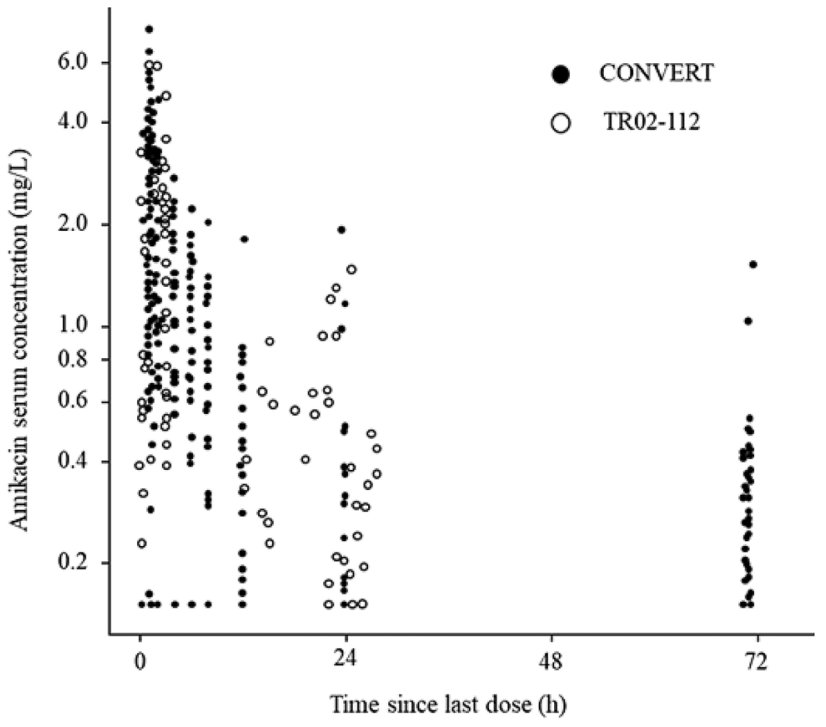

Figure 2 Observed serum amikacin concentration versus time sinces last dose. Closed and open circles represent individual values for patients in CONVERT and TR02-112 studies, respectively. Amikacin concentrations that were BLQ are shown at LLOQ (i.e., $0.15 \mathrm{mg} / \mathrm{L}$ ). One BLQ concentration in the TR02-112 study, observed at $>500 \mathrm{~h}$ after the previous dose, was excluded; it was retained in the population pharmacokinetic dataset but did not impact the model fit. $B L Q$ below the limit of quantification; $L L O Q$ lower limit of quantification

Figure 2: The 24- and 48-hour labels on the $\mathrm{x}$-axis in Figure 2 were transposed. The corrected version of Fig. 2 is given below:

The corrected version of supplementary file is updated here.

Supplementary Information The online version contains supplementary material available at https://doi.org/10.1007/s13318-021-00687-z. 
Open Access This article is licensed under a Creative Commons Attribution 4.0 International License, which permits use, sharing, adaptation, distribution and reproduction in any medium or format, as long as you give appropriate credit to the original author(s) and the source, provide a link to the Creative Commons licence, and indicate if changes were made. The images or other third party material in this article are included in the article's Creative Commons licence, unless indicated otherwise in a credit line to the material. If material is not included in the article's Creative Commons licence and your intended use is not permitted by statutory regulation or exceeds the permitted use, you will need to obtain permission directly from the copyright holder. To view a copy of this licence, visit http://creativecommons.org/licenses/by/4.0/. 